University of Nebraska - Lincoln

DigitalCommons@University of Nebraska - Lincoln

8-29-2005

\title{
Changes in Summer Irrigated Crop Area and Water Use in Southeastern Turkey from 1993 to 2002: Implications for Current and Future Water Resources
}

\author{
Mutlu Ozdogan \\ NASA, ozdogan@hsb.gsfc.nasa.gov \\ Curtis E. Woodcock \\ Boston University, curtis@bu.edu \\ Guido D. Salvucci \\ Boston University \\ Hüseyin Demir \\ Urfa Tuneli Agzi, Sanliurfa, Turkey
}

Follow this and additional works at: https://digitalcommons.unl.edu/nasapub

Part of the Physical Sciences and Mathematics Commons

Ozdogan, Mutlu; Woodcock, Curtis E.; Salvucci, Guido D.; and Demir, Hüseyin, "Changes in Summer Irrigated Crop Area and Water Use in Southeastern Turkey from 1993 to 2002: Implications for Current and Future Water Resources" (2005). NASA Publications. 18.

https://digitalcommons.unl.edu/nasapub/18

This Article is brought to you for free and open access by the National Aeronautics and Space Administration at DigitalCommons@University of Nebraska - Lincoln. It has been accepted for inclusion in NASA Publications by an authorized administrator of DigitalCommons@University of Nebraska - Lincoln. 


\title{
Changes in Summer Irrigated Crop Area and Water Use in Southeastern Turkey from 1993 to 2002: Implications for Current and Future Water Resources
}

\author{
MUTLU OZDOGAN $^{1, *}$, CURTIS E. WOODCOCK ${ }^{2}$, GUIDO D. SALVUCCI ${ }^{2}$ \\ and HÜSEYIN DEMIR ${ }^{3}$ \\ ${ }^{1}$ Hydrologic Sciences Branch, Mail Code 614.3, NASA/GSFC, Greenbelt, MD 20771, USA; ${ }^{2}$ Boston \\ University, Department of Geography, 675 Commonwealth Avenue, Boston, MA 02215, USA; ${ }^{3}$ GAP \\ Regional Development Offices, P.K. 155, Urfa Tuneli Agzi, 63000, Sanliurfa, Turkey \\ (*author for correspondence, e-mail: ozdogan@hsb.gsfc.nasa.gov)
}

(Received: 10 November 2004; in final form: 29 August 2005)

\begin{abstract}
Changes in summer irrigated cropland acreage and related water use are estimated from satellite remote sensing and ancillary data in semi-arid Southeastern Turkey where traditionally dry agricultural lands are being rapidly transformed into irrigated fields with the help of water from the Euphrates-Tigris Rivers. An image classification methodology based on thresholding of Landsat NDVI images from the peak summer period reveals that the total area of summer irrigated crops has increased three-fold (from 35,000 ha to over 100,000) in the Harran Plain between 1993 and 2002. Coupled analysis of annual irrigated crop area from remote sensing and potential evapotranspiration based estimates of irrigation water requirements for cotton indicate a corresponding increase in agricultural water use from about 370 million cubic meters to over one billion cubic meters, a volume in accordance with the state estimates. These estimates have important implications for understanding the rapid changes in current agricultural withdrawals in Southeastern Turkey and form a quantitative basis for exploring the changes in future water demands in the region. For example, expansion of irrigated lands have led to a steady decrease in potential evaporation due to increased roughness and decreased humidity deficit in the Harran Plain. Assuming that the changes in future evaporation conditions will be of similar nature, water use for irrigation is expected to decrease over 40 percent in future irrigation sites. Incorporating this decrease in overall planning of the irrigation projects currently under construction should lead to improved management, and by extension, sustainability of water resources in the region.
\end{abstract}

Key words: agriculture, cotton, CROPWAT, Euphrates, evaporation, irrigation, NDVI, remote sensing, Tigris, Turkey

\section{Introduction}

Turkey is currently engaged in a large integrated water resources development project in its semi-arid Southeastern region. Commonly referred to by its Turkish acronym GAP, the Southeastern Anatolia Project involves 22 dams in the upper Euphrates-Tigris Basin, and aims to provide irrigation for 1.7 million hectares of 
land by 2015 (Ünver, 1997). As in other semi-arid and arid parts of the world, water is a valuable resource in the GAP region. Despite large quantities of water currently available from the Euphrates and Tigris rivers, it is becoming increasingly important to improve management of these resources as further irrigation developments in the upper tri-state (Turkey-Syria-Iraq) Euphrates-Tigris Basin progress. Up-to-date and objective information on the spatial distribution of irrigated crops as well as changes in their areal extent over time can help achieve the goal of efficient water resource management.

The purpose of the research presented here is to provide remote sensing and ancillary data-based estimates of summer irrigated land area and the volume of irrigation water used between 1993 and 2002 in the Sanliurfa-Harran District (Figure 1), where cotton is the primary summer irrigated crop. These estimates form an independent
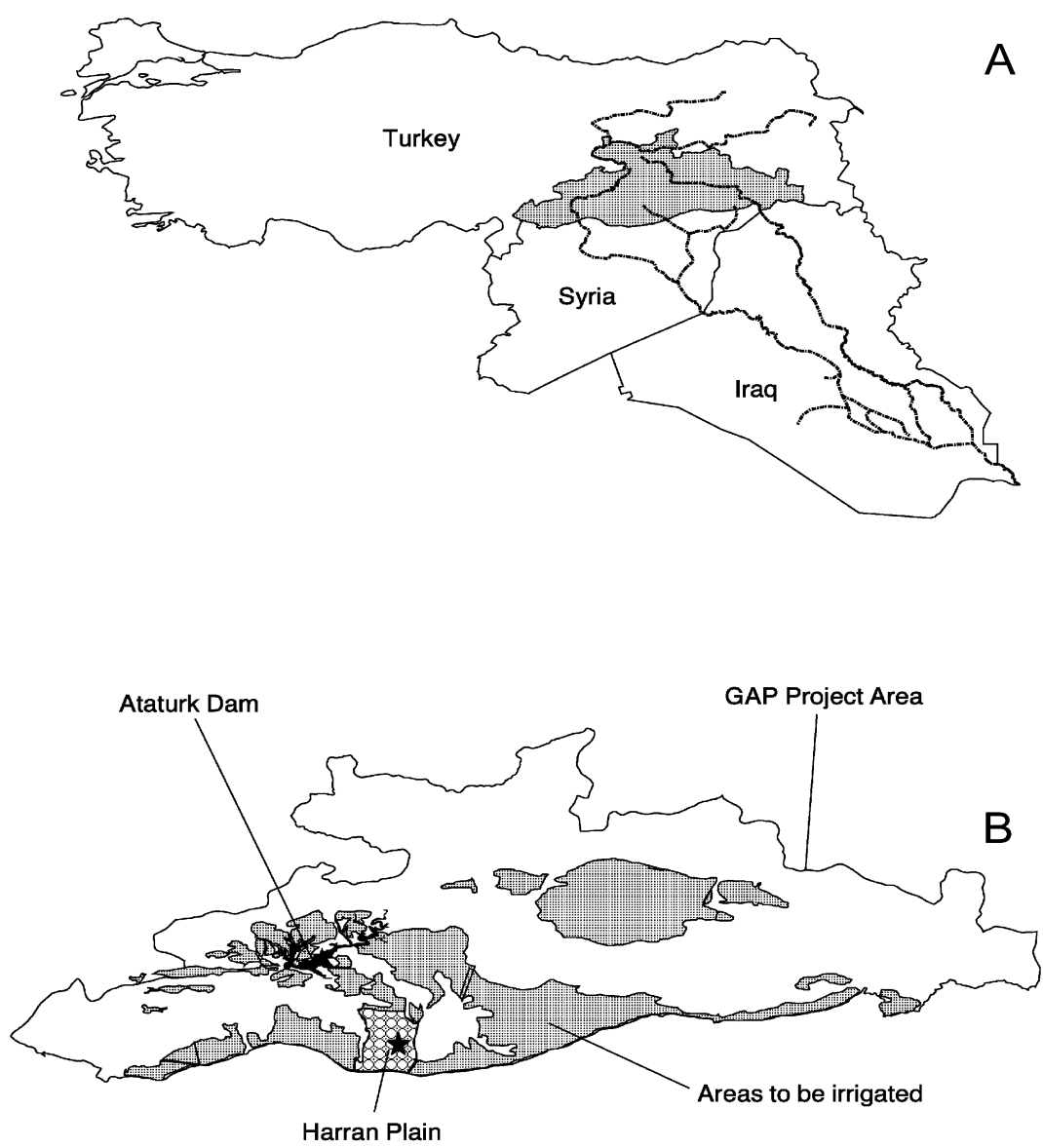

Figure 1. Location of various irrigation projects (shown by the squared pattern) within the GAP region including the Harran Plain (checkered pattern). The black star in the Harran Plain shows the location of the Koruklu Meteorological station. 
data source on rapid changes in agricultural water demand and irrigation development pressure on scarce water resources in Southeastern Turkey. Furthermore, the analysis of climate data within the framework of the so called Complementary Relationship (Bouchet, 1963) for potential evaporation provides a quantitative estimate of potential changes in crop water requirements and hence water withdrawals under future irrigation development scenarios.

\section{Study Area}

The GAP project is situated in Southeastern Turkey and spans approximately 75,000 square kilometers within the upper Euphrates-Tigris Drainage Basin (Figure 1). The Harran Plain, the main focus of this study, is located in the south central part of the GAP project within the Sanliurfa-Harran Irrigation District. The Plain is $30 \mathrm{~km}$ by $50 \mathrm{~km}$ and is located in a region of rolling hills and a broad plateau that extends south into Syria. The area has the major climatic features of the Eastern Mediterranean with a strong continental influence. The mean average temperature is $18^{\circ} \mathrm{C}$ and annual rainfall is around $350 \mathrm{~mm}$. There is significant seasonal variation in precipitation, with most occurring between November and April. The area receives almost no rain during the summer, at which time irrigation becomes necessary.

Several different crops including cotton, cereals, maize, and vegetables are cultivated in the Harran Plain. While there is a variety, cotton and cereals dominate the agricultural scene in any given year. With the inauguration of the irrigation projects, cotton has increasingly become a popular irrigated crop, mainly due to its cash crop status as well as non-significant management and storage requirements. In fact, for the 2002 growing season, cotton accounted for over $85 \%$ of all crops (both irrigated and non-irrigated) while cereals had less than a 15\% share of the Harran Plain (Demir, 2003). In terms of irrigated crops only, cotton accounted for over $96 \%$ while the remaining four percent was shared by supplemental cereal irrigation, second crop maize, and vegetables. Contrary to common expectations, current agrarian practices in the Harran Plain allow production of a single crop per year primarily due to a large temporal overlap in growth schedules between different crops (Figure 2). For example, while cotton (the main summer irrigated crop) is planted in early- to mid-April, cereals (predominantly rain-fed) are harvested in mid- to late-May, making it impossible for a single agricultural field to support both cereals and cotton in the same growing year. Thus, if a field has supported cereals, it commonly remains fallow until the next production year.

The Turkish State Hydraulic Works (DSI) is the government agency responsible for the design and construction of irrigation facilities in the GAP region. DSI developed most of the irrigation schemes in the study area with the aim of managing their operation and maintenance, typically retaining responsibility for supply systems from the source down to the tertiary-level systems within fields. However, due to the highly subsidized nature of irrigation water, collected fees are insufficient to meet the cost of maintaining the system. To increase local participation and to 


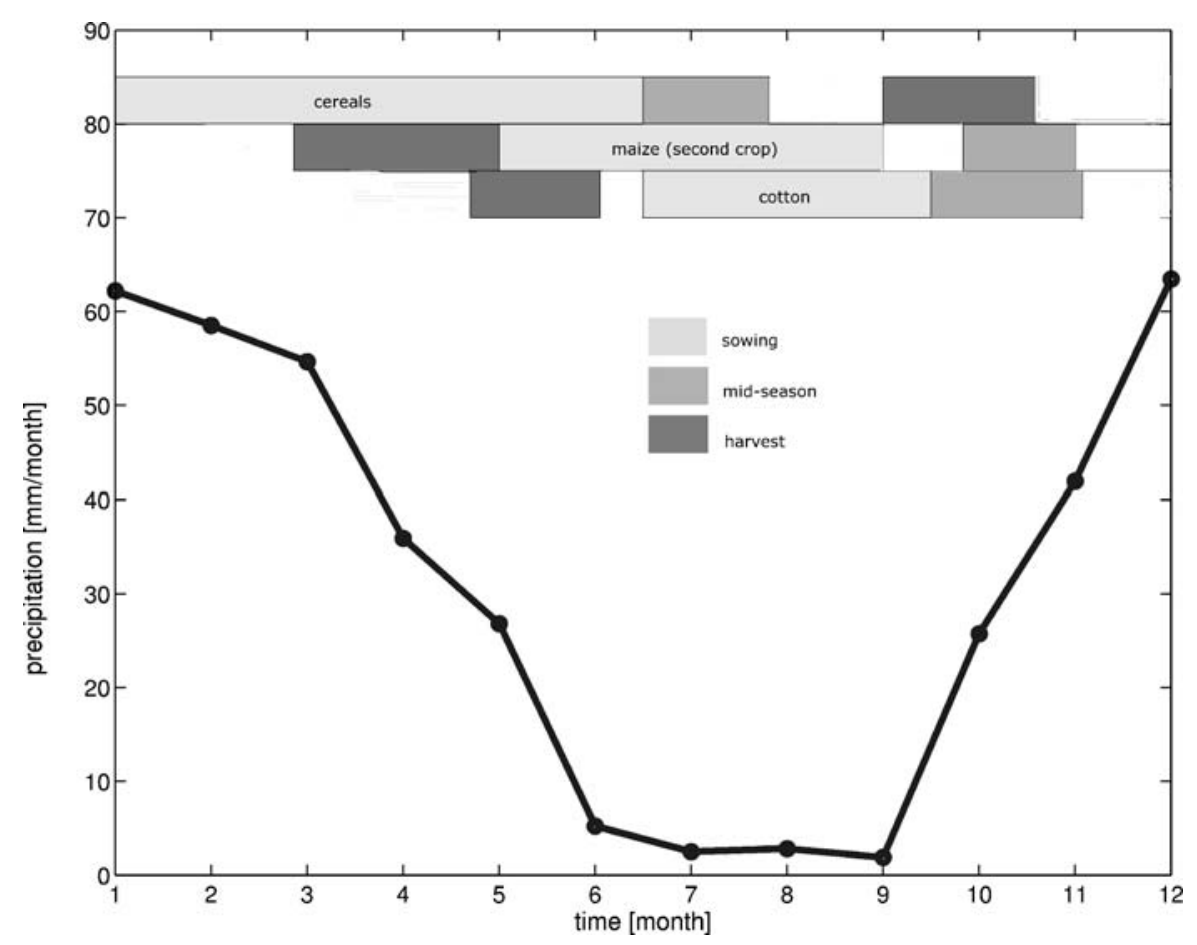

Figure 2. Crop schedule and precipitation availability in the Harran Plain. The precipitation data (thick black line) represents the 30 year average for four stations in and around the Harran Plain.

improve management of land and water resources while minimizing the burden on the State (DSI), a total of 18 irrigation unions were gradually established in the Harran Plain Irrigation District. Each year, farmers within each irrigation union report on the amount of land they irrigated along with the type of crops cultivated. This information is collected by the unions and reported to the DSI's Operations and Maintenance Division and subsequently published annually. However, given the politically charged nature of irrigation, there is a concern that reported amounts of irrigated area may not represent the true irrigated area. It is one of the intents of this study to provide an independent estimate of irrigated area for each irrigation union in the district over the course of the study period.

\section{Methodology}

The task of monitoring changes in summer irrigated crop area and related water use in the Harran Plain, as well as the potential changes in crop water requirements under different irrigation impact scenarios in other GAP irrigation project areas 
require multiple sources of data, analyzed consecutively using the appropriate tools. In the first part of this study, carefully timed remotely sensed data were used to map the location and extent of irrigated summer crops on an annual basis between 1993 and 2002. In the second part, information on summer irrigated crop water requirements were combined with the areal extent of summer irrigated crops to determine, conservatively, the annual volume of irrigation water use. In the third part, a simple analysis based on the Complementary Relationship was used to predict potential changes in crop water requirements. The methodology for each of these tasks is provided in detail below.

\subsection{REMOTE SENSING OF SUMMER IRRIGATED CROPS}

Remote sensing has been an effective tool for monitoring irrigated lands under a variety of climatic conditions and locations. It provides synoptic and timely coverage of agricultural lands in several spectral regions and archived data allow comparison of images across dates, yielding change over time. To date, a number of studies have used remotely sensed imagery, primarily at high spatial resolutions such as Landsat, to monitor irrigated agriculture. Early work concentrated on determining the ability of remotely sensed imagery to map and update irrigated land acreage mainly in the US and India (Draeger, 1976; Heller and Johnson, 1979; Thiruvengadachari, 1981; Kolm and Case, 1984; Thelin and Heimes, 1987; Rundquist et al., 1989). More recent studies have developed and tested new classification methods specifically suited for mapping irrigated lands (Eckhardt et al., 1990; Ram and Kolarkar, 1993; Pax-Lenney et al., 1996; Abuzar et al., 2001; Martinez-Beltran and CaleraBelmonte, 2001).

The results of these studies indicate that remote sensing-based applications for irrigation monitoring are at a mature stage of development. The methods used in these studies provide the knowledge base for the work undertaken in this research. For instance, there is overwhelming consensus on the efficiency of vegetation indices such as the Normalized Difference Vegetation Index (NDVI) in identifying irrigated fields, if carefully timed images are available. Furthermore, it has been consistently shown that while single date imagery, acquired at the height of the growing season, maybe sufficient to identify irrigation, multi-date data is needed to distinguish different irrigated crop types (Thiruvengadachari, 1981; Rundquist et al., 1989; Abuzar et al., 2001).

In remote sensing based studies of irrigated lands, imagery with high spatial resolution is necessary to accurately locate irrigated fields and map their areal extent with sufficient detail (Pax-Lenney and Woodcock, 1997). Landsat Thematic Mapper (TM) was chosen as the image data source for this study due to its relatively fine spatial resolution $(30 \mathrm{~m})$, as well as spectral bands that are well suited to monitoring green vegetation, existence of archival imagery, and relative affordability. Analysis by Ozdogan (2004) indicates that in Southeastern Turkey, the best time to distinguish irrigated lands from other land cover types is mid-to-late summer. 
Table I. Characteristics of the Landsat data used in the study. TM - Landsat Thematic Mapper sensor, ETM - Landsat Enhanced Thematic Mapper Plus sensor.

\begin{tabular}{lll}
\hline & Date & Sensor \\
\hline 1 & August 23, 1993 & TM \\
2 & August 26, 1994 & TM \\
3 & August 15, 1996 & TM \\
4 & August 2, 1997 & TM \\
5 & August 21, 1998 & TM \\
6 & September 1, 1999 & ETM+ \\
7 & August 18, 2000 & ETM+ \\
8 & September 2, 2001 & ETM+ \\
9 & August 24, 2002 & ETM+ \\
\hline
\end{tabular}

Based on this information, nine late-summer, near-yearly Landsat images (WRS2 path/row 173/034) for the period between 1993 and 2002 were acquired and analyzed (Table I) (the 1995 image was not available).

The nine Landsat images were first registered to each other and to a common map reference system. Image radiometric normalization was also undertaken to minimize variation in image values caused by non-surface related factors, such as atmospheric conditions, sun angle, and sensor calibration. Such normalization also enabled the use of image classification rules developed from a single date of imagery to be reliably applied to images from other dates.

Studies of agricultural lands using multi-spectral imagery has shown that NDVI is a sufficiently good indicator of irrigation presence (Kolm and Case, 1984; Eckhardt et al., 1990; Abuzar et al., 2001; Martinez-Beltran and Calera-Belmonte, 2001), irrigation status (Pax-Lenney et al., 1996), crop condition (Wiegand et al., 1992), evaporation (Roerink et al., 1997), as well as large scale vegetation dynamics (Tucker et al., 1984). For each study year, NDVI was generated using the following well known formula:

$$
\mathrm{NDVI}=\frac{\mathrm{TM}_{4}-\mathrm{TM}_{3}}{\mathrm{TM}_{4}+\mathrm{TM}_{3}}
$$

In (1), $\mathrm{TM}_{4}$ denotes Landsat $\mathrm{TM}$ Band 4 (Near Infrared), $\mathrm{TM}_{3}$ denotes Band 3 (Red), both in units of normalized DN values. NDVI ranges between -1 and +1 but values below 0 and above 0.8 are rarely encountered.

In the procedure presented in this study, individual pixels corresponding to irrigated or non-irrigated lands for each study year were classified using NDVI thresholds. This approach is based on identifying a range of NDVI values that represent a particular land cover (i.e. summer irrigated). This is a simple but an 
effective way of highlighting internally homogeneous areas such as irrigated agricultural fields within an image. While the NDVI threshold methodology is a fast and easy method to classify remotely sensed imagery, the quality of analysis is highly dependent on the quality of chosen thresholds. To determine the best possible thresholds, a total of 81 sites, which correspond to image based polygons, were used to extract NDVI values corresponding to irrigated and non-irrigated classes. The sites ranged in size from 2 pixels ( $0.16 \mathrm{ha}$ ) to 42 pixels ( $3.41 \mathrm{ha})$ and were all field visited in the summer of 2002. Each site (polygon) was labeled as summer-irrigated or non-irrigated (spring irrigated, rain-fed, fallow, urban, water etc.) for the current year based on the field observations. Irrigation related information for each site for previous years (1993-2001) was obtained through interviews with local farmers who provided detailed information on the past irrigation activities (if applicable) on each site. Consequently, based on the presence/absence of summer irrigation at each site, a meaningful lower limit of NDVI that effectively separated irrigated lands from other land cover types for each study year was obtained.

Application of thresholds to each NDVI image for each study year resulted in nine maps showing the distribution of summer irrigated lands in the Harran Plain. Using the area of each image pixel $\left(\sim 900 \mathrm{~m}^{2}\right)$ these maps also provide information on changes in area of summer irrigation over time. In Figure 3, four of these maps are displayed as a time series showing the changes in the extent and spatial distribution of irrigation in the Harran Plain.

Quality assessment was carried out individually for each map. Forty sites per map, each one pixel in size, were selected using a stratified random sample process (Hay, 1979). These sites were labeled as irrigated and non-irrigated based on field obtained information for the current year and by visual interpretation of the NDVI images for previous years. Thus, it was possible to identify the overall class accuracy for each map using these sites. These accuracies also reflect the quality of irrigated area estimates. Results of the quality assessment show that the map accuracies range from 95.83 to $99 \%$ with the mean overall accuracy of $98.11 \%$, illustrating the strength of the NDVI thresholding approach.

\subsection{IRRIGATION WATER USE}

The primary mechanism for consumptive use of water by irrigated crops in the Harran Plain is evapotranspiration. Due to a large interest in construction of efficient irrigation structures as well as maintaining sustainable use of water resources in the region, many different institutions have conducted work to quantify crop consumptive use for each irrigation district within the GAP area. These institutions include the DSI, the main government agency responsible for the construction and maintenance of irrigation schemes, as well as independent research universities. Below, the methodology and results from this study as well as the works of the above-mentioned institutions are provided. 

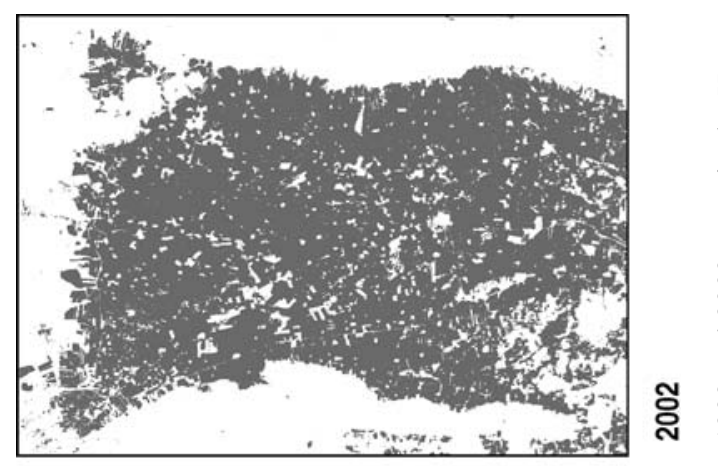

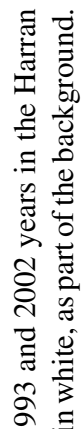

กิ ڤ.

षี

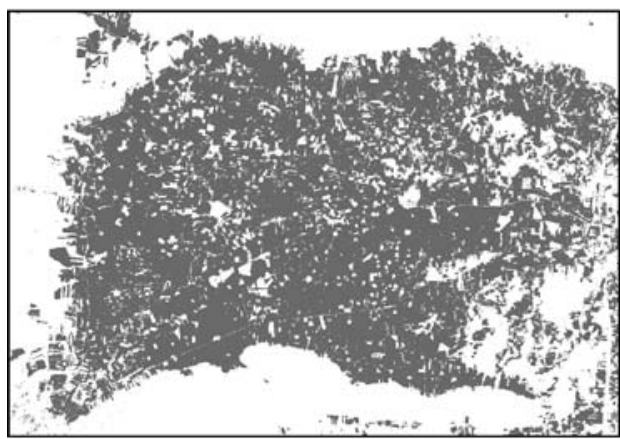

运

)

$\frac{0}{2}$

苛

పิ

రั

氙

\% :

을

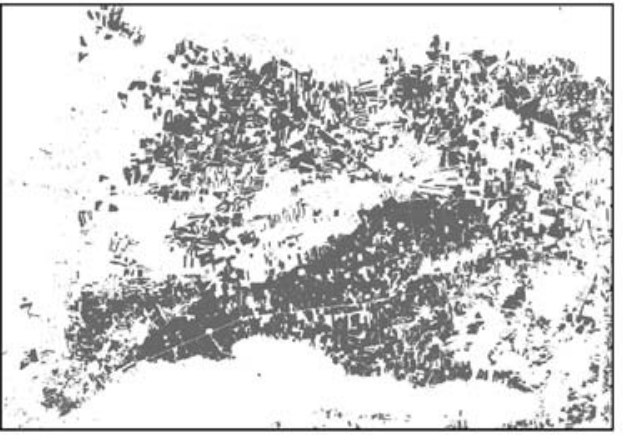

萬

$\Xi$

离高

苛焉

눙

흘

苋

:

요 䭴

윰

을

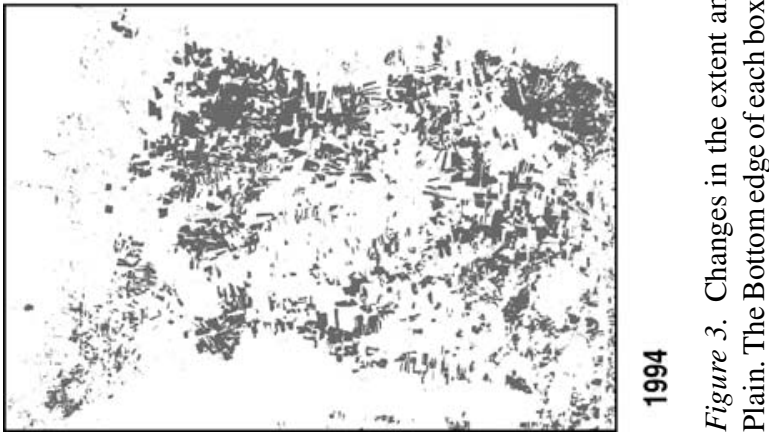


In this study, crop water consumptions in the Harran Plain were computed with the help of the popular CROPWAT system (Smith, 1992). CROPWAT is a computer program designed to calculate crop water requirements (CWR) from climatic, crop, and soil characteristics data. Furthermore, the program allows the development of irrigation schedules for different management conditions and the calculation of scheme water supply for varying cropping patterns. The CROPWAT program first computes Penman-Montheith-based reference (potential) evapotranspiration (ETp) and then adjusts this generalized variable for each crop using seasonal growth curves, or so called $K_{c}$ parameters:

$$
\mathrm{CWR}=\sum_{d} \mathrm{ET}_{p} * K_{c}
$$

where $\mathrm{d}$ is the time step, usually 10 days.

For the Harran Plain, monthly averaged values of air temperature, humidity, wind speed, and solar duration data, observed at the Koruklu meteorological station (shown by the black star on Figure 1) were used as inputs to the CROPWAT program for each study year between 1993 and 2002. The general meteorological conditions in the Harran Plain are represented in Table II as 23-year monthly means. The CROPWAT program also requires general information on soil characteristics as well as crop schedule. Data on general soil properties of the Harran Plain were taken from Karaata (1985).

As described earlier, cotton is the dominant summer irrigated crop in the Harran Plain, accounting for over 96 percent of all summer irrigated crops. Thus, it was relatively safe to assume cotton consumptive use as being representative of the agricultural water use in the entire Plain. CROPWAT results averaged over the entire study period are given in Table III. Note that each year's irrigation requirements (not shown) are found to be slightly decreasing between 1993 and 2002, primarily because of decreased potential evaporation. Explanation and implications of this decline are given below as well as in Ozdogan and Salvucci (2004).

Also provided in Table III are several consumptive use estimates calculated by different studies mentioned above. The differences in these estimates underscore differences in their method of calculation. The DSI (both 1988 and 1992) estimates are based on the modified Blaney-Criddle (Doorenbos and Pruitt, 1977) method that only uses air temperature data. This approach often produces significant variation between computed consumptive use values and those obtained from lysimeter measurements. These errors are known to be especially high in semi-arid, highaltitude environments, leading to significant underestimation (Jensen et al., 1990). All other estimates listed in Table III are calculated based on the Penman-Monteith method.

The effective rainfall for each year must be subtracted from the crop consumptive use to obtain the net consumptive irrigation requirement. US Bureau of Reclamation (USBR) method is chosen for this task in the CROPWAT model. USBR method 


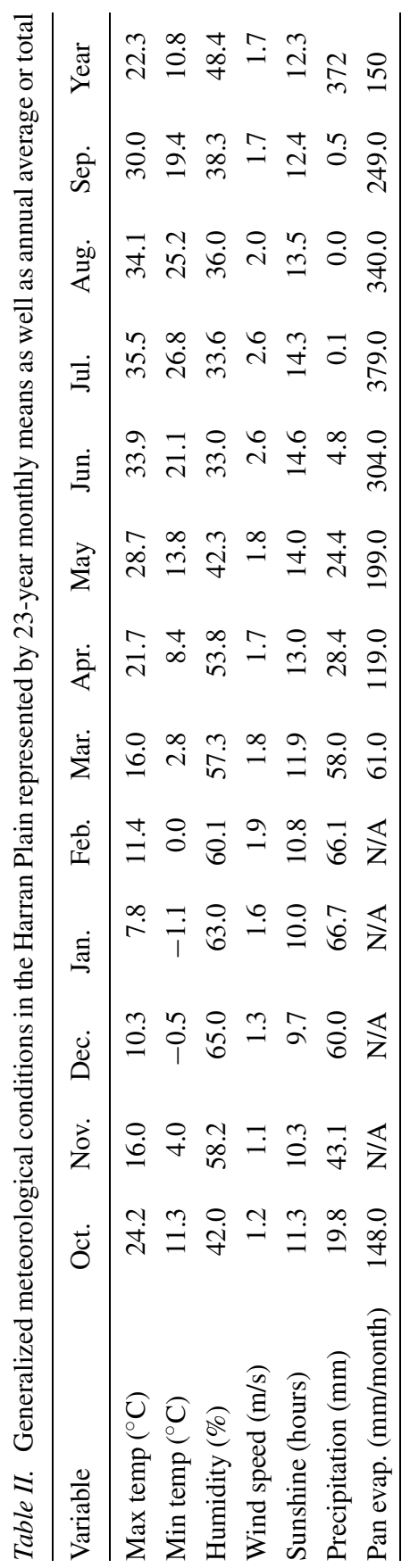


Table III. Comparison of different Crop Water Requirements (CWR)

\begin{aligned} & \hline CWR Reference \\ & \hline 1443 This study (10-year mean) \\ & 651 DSI, 1992 \\ & 711 DSI, 1988 \\ & 1168 GAP, 1992 \\ & 1174 Beyribey, 1992 \\ & 1224 Kodal et al., 1997 \\ & 1325 Karaata, 1985 \\ & \hline\end{aligned}

linearly relates effective rainfall to the average monthly rainfall where different linear relationships are used for different ranges of rainfall.

It is important to note here that the derived net consumptive use will overestimate actual consumptive use in situations where crop consumption is limited by water availability, plant vigor, or other factors. In this study, it was assumed that there was no limitation to water availability (irrigation is present throughout the growing season), and that no major plant disease was present in all years.

The combination of data on the area of summer irrigated crops with seasonal consumptive irrigation requirements for cotton provides the tool to determine the volume of irrigation water demand on an annual basis between 1993 and 2002. For this, each year's summer irrigated area obtained from remote sensing was multiplied by the consumptive requirements for cotton. As a result, annual volume of water demand was calculated for ideal conditions where there is no loss of yield and onfarm irrigation and conveyance efficiencies are 100 percent. These results reflect the lower bound on consumptive irrigation use in the Harran Plain. Factoring in the conveyance efficiencies from the source to the field (as low as 51\%) (Demir, 2003), the actual volume of water is probably higher provided that no significant losses in yield are permitted.

\subsection{POTENTIAL CHANGES IN FUTURE AGRICULTURAL WATER DEMAND}

The work by Ozdogan and Salvucci (2004) on the possibility that the feedback between atmospheric evaporative demand and terrestrial evaporation may change as a function of irrigated area lends credibility to the hypothesis of complementarity, suggesting that large scale irrigation have the potential to strongly affect the amount of water required for that irrigation. This finding may have great significance for future management of water resources within the GAP project area. For example, assuming that future irrigation projects will influence the atmospheric demand for evaporation similarly to that observed in the Harran Plain, significant reductions in crop water requirements in future irrigated sites can be expected. If these reductions are realized, they imply large water savings. Moreover, GAP irrigation projects 
utilize waters of both the Euphrates and Tigris rivers, two of the key water resources in the Middle East and the subject of potential water-related conflicts between upper (Turkey) and lower (Syria \& Iraq) riparian countries. Future irrigation-induced changes in crop water requirements in the positive direction, for example, may positively influence the relationship between these countries, when it comes to sharing water.

Here, a simplified approach based on the Complementary Relationship (Bouchet, 1963) is presented as way to quantitatively predict potential reduction in crop irrigation demand in future irrigated sites in the GAP region. The Complementary Relationship is based on the concept that there are feedback processes between water availability at the surface and evaporative demand of the overlying atmosphere. Under conditions of constant energy input, these processes lead to a strong coupling between actual $\left(E_{a}\right)$ and potential $\left(E_{p}\right)$ evaporation showing a complementary structure (Ozdogan and Salvucci, 2004). Here, $E_{p}$ is defined as the evapotranspiration that would take place from a moist surface under prevailing atmospheric conditions. Under conditions where $E_{a}$ equals $E_{p}$, this rate is referred to as the wet environment evaporation $\left(E_{w}\right)$ (Morton, 1965).

Bouchet (1963) hypothesized that under conditions of minimal advection, when actual evapotranspiration $\left(E_{a}\right)$, falls below its potential rate $\left(E_{w}\right)$, a certain amount of energy $(Q)$ becomes available

$$
\lambda E_{w}-\lambda E_{a}=Q
$$

This excess energy not used for evapotranspiration would become available to warm the atmosphere and soil. Increased air temperature due to this warming and decreased humidity due to reduced evapotranspiration lead to an increase in potential evaporation $\left(E_{p}\right)$ under the new "potential" conditions:

$$
\lambda E_{w}+Q=\lambda E_{p}
$$

Equations (1) and (2) lead to the Complementary Relationship:

$$
\lambda E_{a}=2 \lambda E_{w}-\lambda E_{p}
$$

If water availability at the surface is increased, for example through irrigation, the reverse process occurs, and $E_{p}$ decreases as $E_{a}$ increases. Thus, potential evaporation measured over a region becomes both the result and a cause of actual evaporation measured over the same region.

To forecast the changes in crop water requirements under a future irrigation scenario in four selected project areas (Table IV) within the GAP, potential evaporation for the current study year (2002) in each area, computed with the help of the Penman-Monteith equation, was linearly extrapolated along the wetness (irrigation) axis of the Complementary Relationship (Figure 4). The assumption here is that 
Table IV. Characteristics of the four irrigation projects considered for changes in future irrigation water demand under different irrigation development scenarios. Potential evaporation (Ep) is for the growing season (June, July, August) average

\begin{tabular}{llc}
\hline Project & Location & Ep (mm/day) \\
\hline Adiyaman & North of Ataturk Dam & 8.5 \\
Siverek & East of Ataturk Dam & 11.5 \\
Ceylanpinar & South Central GAP & 8.1 \\
Batman & East Central GAP & 8.2 \\
\hline
\end{tabular}

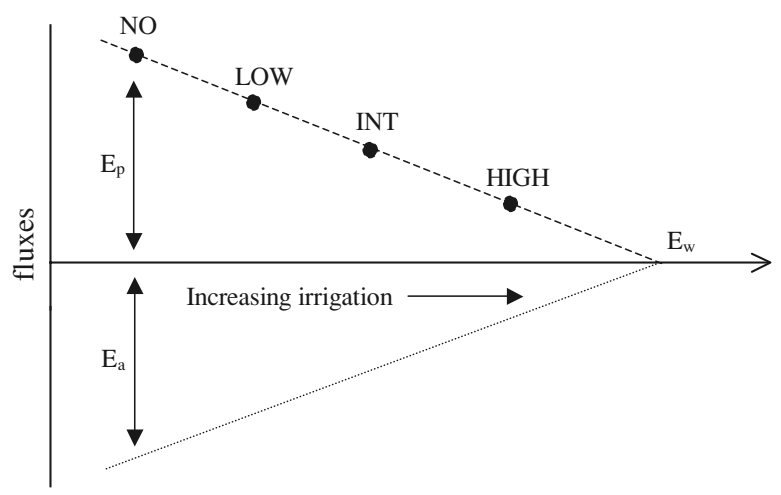

Figure 4. Schematic representation of the Complementary Relationship and different irrigation impact scenarios. NO: no impact; LOW: low (25\%) impact; INT: Intermediate (50\%) impact; HIGH: high (75\%) impact; $E_{a}$ : Actual evaporation; $E_{p}$ : potential evaporation; $E_{w}$ : is wet-environment evapotranspiration (theoretical lower limit of potential evaporation). The horizontal axis represents the wetness axis, increasing to the right.

any future irrigation-induced changes in potential evaporation should theoretically occur between its current value and its lower limiting value of the wet environment evaporation or $E_{w}$, which, based on the results from the Harran Plain, will remain constant (Ozdogan and Salvucci, 2004). By choosing appropriate thresholds between current $E_{p}$ and $E_{w}$ along the wetness axis, it was possible then to determine a new potential evaporation value for any impact scenario for each irrigation project area (Figure 4). This new value of $E_{p}$ was later used in the CROPWAT crop water consumption model, to predict changes in irrigation demand for different crops under different irrigation scenarios in each of the four irrigation project areas.

The quantities, $E_{p}$ and $E_{w}$ were computed using ensemble data from multiple meteorological stations, representing all future irrigated sites (Figure 1). The reliability and adequacy of these data for climate analysis has been verified by previous studies (Kadioglu, 1998; Kadioglu and Cepniler, 1998). The data were used to compute monthly means for 27 years. The current (pre-irrigation) conditions for 
each month were then computed by averaging these 27 -year monthly data after removing the outliers identified as greater/less than two standard deviations $(2 \sigma)$ from the mean.

To determine the irrigation-induced changes in potential evaporation, five impact scenarios were considered: $N O$, no impact case where potential evaporation is unaffected by irrigation; $L O W$, low impact case where potential evaporation decreases only by 25 percent with respect to $E_{w}$; INT, intermediate impact occurs where $E_{p}$ decreases by 50 percent with respect to $E_{w} ; H I G H$, high impact case where $E_{p}$ decreases by 75 percent with respect to $E_{w}$, and $E_{W}$ where $E_{p}$ reaches its lower limit, the $E_{w}$ impact already realized in the Harran Plain. Note that these scenarios represent a very conservative approach to impact assessment. In essence, what is referred to as HIGH in these scenarios has already been observed in the Harran Plain. Also note that in these scenarios, percent decrease is defined as the percentage of the difference between $E_{p}$ and its theoretical lower limit of $E_{w}$. In other words, a fifty percent decrease in $E_{p}$ with respect to $E_{w}$ does not mean a fifty percent decrease in absolute magnitude of $E_{p}$. To determine a new $E_{p}$ value under each of these impact cases, the given percentage difference between $E_{p}$ and $E_{w}$ was subtracted from potential evapotranspiration. These values were used in the CROPWAT model to determine seasonal irrigation requirements for a variety of crop types, planned to be grown in each of the four project area (DSI, 1988). Irrigation requirements for the entire area of each irrigation project were then calculated as a weighted sum of each crop's individual requirements and percent cultivation. The results are presented in Table V.

\section{Results}

The aim of this work was to monitor changes in irrigated area and related water use in the Harran Irrigation District. Moreover, future potential agricultural water demand in the entire GAP area is computed using a simple approach based on the Complementary Relationship. Three types of results are presented. The first is related to the summer irrigated acreage estimated with remote sensing (Figures 3 and 5a). In the Harran Plain, 101,524 ha were identified as irrigated as of 2002 in all irrigation unions, accounting for approximately $76 \%$ of the total land area of the districts. This is a $\sim 289 \%$ increase from 1993, when the total irrigated area was only 35,179 ha, representing roughly $26 \%$ of the total area of irrigation unions. Analysis of irrigated lands for each year reveals that the rate of expansion has not been uniform. A total of 37,813 ha was irrigated as of 1994, 60,816 ha as of 1996, an additional 26,586 ha (adding up to 87,403 ha) as of 1998, and an additional 12,082 ha (adding up to 99,485 ha) as of 2001, before reaching a peak in 2002 (Figure 5a). Results also reveal information on the spatial pattern of expansion within the Harran Plain (Figure 3). While irrigation occurred in the central parts of the Plain between 1993 and 1999, irrigation expanded at the margins of the plain for the last three years, reclaiming marginal lands with the introduction of irrigation. Furthermore, 


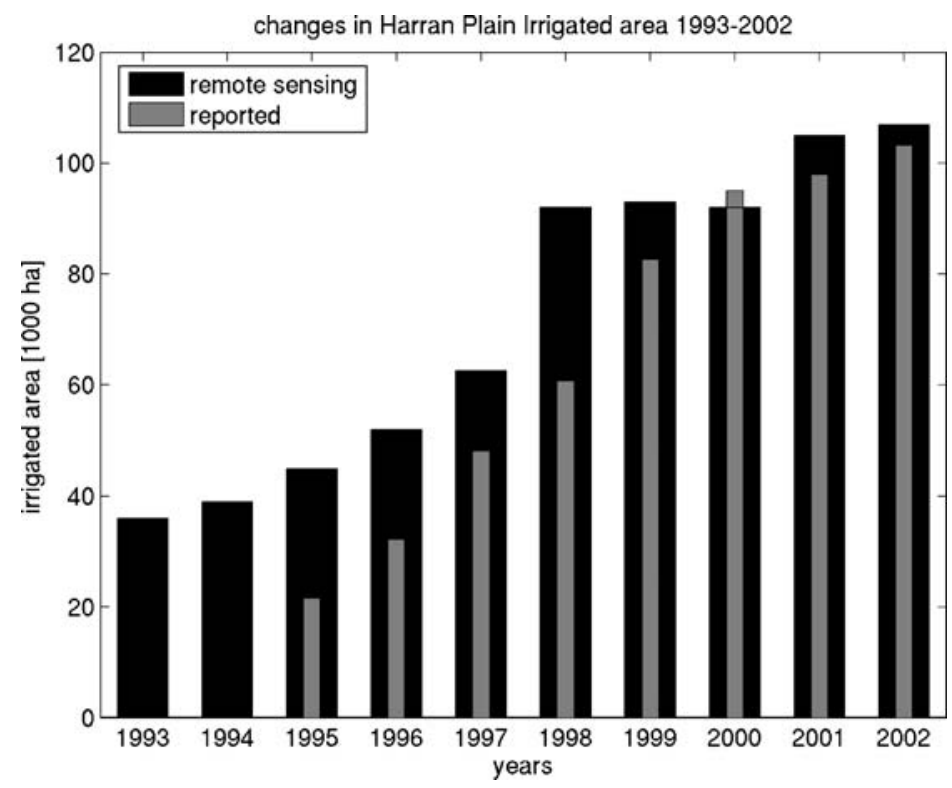

(a)

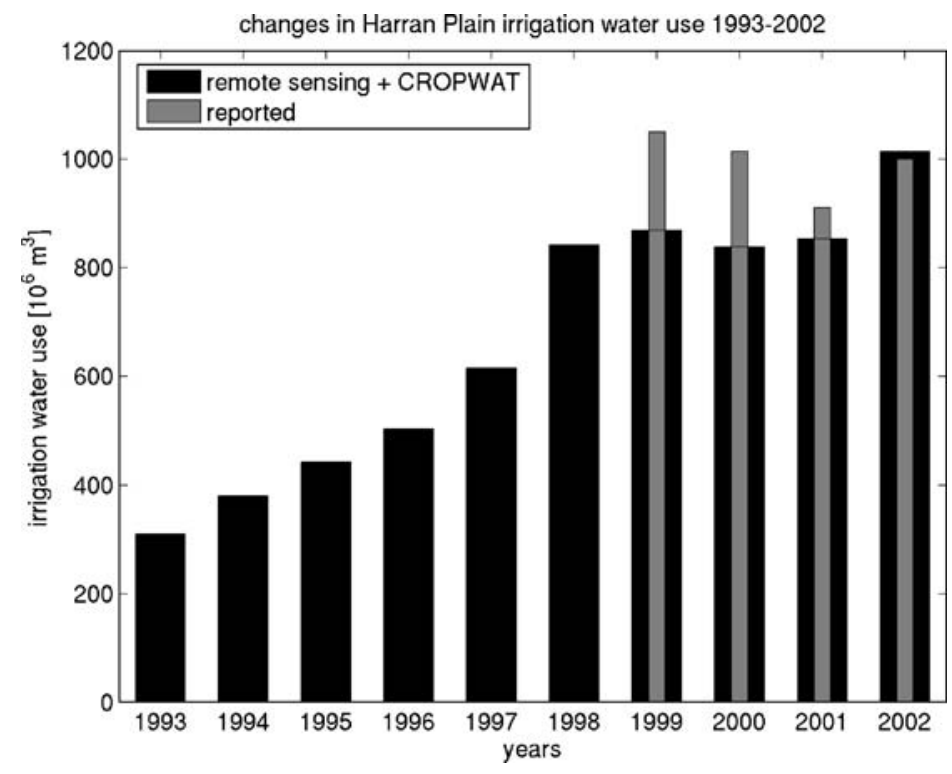

(b)

Figure 5. (a) Changes in irrigated area estimated from remote sensing (black) and reported by the DSI (grey) in the Harran Plain between 1993-2002. Note that remote sensing based estimate of irrigated area for year 1995 does not exist, the shown data is interpolation result between 1994 and 1996. (b) Changes in agricultural water use as estimated by coupling remote sensing crop area and CROPWAT-based crop water requirements (black) in the Harran Plain between 1993 and 2002. Also shown is actual flow data (after correction for discharge) made available to the Harran Plain for irrigation for years 1999-2002 (grey). 
field observations reveal that almost all of the summer irrigated lands have been converted from existing, traditionally rain-fed agricultural lands. Conversion of grasslands to irrigated fields with increased availability of water was minimal.

As stated above, these results correspond to all individual irrigation unions within the irrigation District. Of the total 18 irrigation unions, the northern and eastern 15 are surface irrigated while the southern three mostly use groundwater pumped irrigation. Estimates of irrigated area were also examined for each of the 15 surface water irrigated unions (the southern three were excluded) for years 1999, 2000, and 2001 as these were the only years with available reported areas. The results show that the remote sensing-based summer irrigated land area for these three years are slightly higher. Statistical relationship between the two estimates produces a root mean squared error (RMSE) of $865 \mathrm{ha}$. One possible reason for the difference is underreporting of the irrigated area by the irrigation unions. Since the price of irrigation water is based on the amount of land irrigated, there is tendency by farmers to underreport the actual area cultivated. The trend in difference between reported and remote sensing based estimates of irrigated area in the Harran Plain also exists for the total area irrigated area. In Figure 5a, we show that the reported estimates (obtained from DSI) are constantly less than remote sensing estimates between 1995 and 2002 (except for year 2000), further indicating the potential problem of underreporting of irrigated area.

The surface area occupied by irrigated crops is the main parameter influencing the system-wide water extraction as well as the degree to which irrigation affects the components of the hydrologic cycle. While, there is a need for multi-temporal imagery in distinguishing summer crops, this study shows that in the study area, methods such as NDVI thresholding based on single images produces useful results, especially if guided with high frequency remote sensing observations (Ozdogan, 2004). This is particularly important for incorporating remote sensing technology into the future irrigation management practices in the GAP region. While the method for remote detection of summer irrigated lands used here is simplistic, it provides an excellent example of the practical utility of remote sensing for summer irrigation monitoring, at least in the GAP region.

The second result concerns changes in the amount of irrigation water used in the Harran Plain. Since the principal parameter influencing water use is the surface occupied by irrigated crops, as amounts of irrigated land increases through time, water use for irrigation increases dramatically. Using the cotton irrigation requirements provided above, each year's irrigated area is converted to water use (Figure 5b) by simply multiplying annual crop requirements by irrigated area. Results indicate that between 1993 and 2002, the volume of irrigation water used increased three-fold from less than 370 million cubic meters to over 1 billion cubic meters, paralleling the increase in irrigated area. Note however, that year-to-year changes in irrigated area and water used were not always similar. This is because for each consecutive year, irrigation water requirements are lessened due to decrease in potential evaporation (Ozdogan and Salvucci, 2004). Nevertheless, there was 
a steady increase in water consumption in the Harran Plain, closely following the increases in the number of water delivery structures that made surface water irrigation possible in the first place.

Figure $5 \mathrm{~b}$ also includes data (after corrected for discharge) on the amount of water released to the Harran Plain from the Sanliurfa tunnels for the purposes of irrigation (gray vertical bars shown on years 1999-2002). For each of these years (except in 2002), the reported flow data exceeds remote sensing based estimates of agricultural water use. One explanation for this difference is related to irrigation and water transport efficiencies. It is important to note here that with the use of only the crop consumptive requirements, the results presented here represent the lower bound on the actual volume of water use. Results shown in Figure $5 \mathrm{~b}$ do not factor in the in-farm irrigation and conveyance efficiencies. When corrected for these efficiency losses (e.g. Beyribey, 1992), the estimates of this study could be well within observed agricultural water use in the Harran Plain.

Finally, Table $\mathrm{V}$ shows the potential changes in crop water requirements for different future irrigated sites under different irrigation impact scenarios. Overall irrigation requirements for each project area are calculated as a weighted sum of individual crop water requirements that take into account the percent cultivation. The results are vastly different for different irrigation project in the GAP area. For example, in the Adiyaman Project, 13\%, 25\%, and 38\% decrease in average crop water requirements can be expected under low, intermediate, and high impact scenarios, respectively. With a planned irrigated area of 68,000 hectares, the decrease under the high impact scenario translates into over 200 million cubic meters of water savings. Within the more arid Siverek irrigation project, on the other hand, the decrease in crop water requirements can be as high as $47 \%$ under a high impact scenario, translating to over 400 million cubic meters of water, annually. Overall, the analysis based on the complementary relationship suggests that a $40 \%$ average decrease in all major project areas is possible.

The computed crop water requirements under future irrigation scenarios assume successful crop growth without a loss in yield. Moreover, no limitations due to water

Table V. Changes in CWR under different irrigation impact scenarios. NO: no impact; LOW: low (25\%) impact; INT: Intermediate (50\%) impact; HIGH: high (75\%) impact; $E_{w}$ : is wet-environment evapotranspiration (theoretical lower limit of potential evaporation). See text for explanation. Average represent the area weighted average

\begin{tabular}{lccccccccc}
\hline & NO & LOW & $\%$ & INT & $\%$ & HIGH & $\%$ & $E_{W}$ & $\%$ \\
\hline Adiyaman & 573 & 498 & 13.1 & 428 & 25.3 & 355 & 38.1 & 283 & 50.6 \\
Siverek & 913 & 768 & 15.9 & 623 & 31.3 & 482 & 47.3 & 347 & 62.0 \\
Ceylanpinar & 679 & 597 & 12.2 & 514 & 24.3 & 432 & 36.4 & 352 & 48.2 \\
Batman & 711 & 620 & 12.8 & 529 & 25.6 & 441 & 38.0 & 351 & 50.6 \\
Average & 719 & 621 & 13.6 & 524 & 27.2 & 428 & 40.5 & 333 & 53.7 \\
\hline
\end{tabular}


availability and plant disease were assumed. To calculate the amount of water that must be present at the reservoir (both surface and underground), the crop water requirements must be corrected for conveyance and application losses. Unfortunately, both distribution and irrigation efficiencies in GAP irrigation projects are low, on the order of 90 to $100 \%$ for conveyance and 60 to $85 \%$ for in-farm application (Demir, 2003). When corrected for these losses, the potential changes in irrigation crop consumptive requirements may even be more significant.

\section{Discussion}

In the semi-arid parts of the world with finite trans-boundary water resources, as exemplified by the GAP region, accurate and objective information on increases in irrigated land area and related changes in consumptive water use are essential components of developing irrigation sustainability. The two key parameters influencing this sustainability are the volume of water withdrawn from the system and the strong possibility that the size of evaporating crop area will have impacts on regional hydroclimatology.

The results of this study show that the current trends in agricultural water withdrawal from the upper reaches of the Euphrates River (through the reservoirs) to supply irrigation water for the Harran Plain exceeds a billion cubic meters per annum. The total average annual flow of the Euphrates is 35.58 billion cubic meters, to which Turkey contributes more than $88 \%$ (Gruen, 2000). While the amount of water used in the Sanliurfa-Harran District represents a mere three percent of this flow, irrigation schemes in this district also represent only eight percent of the total land area to be irrigated by 2015 (Ünver, 1997). When all of the planned irrigation schemes are operational (up to 1.7 million hectares), irrigation will be a large component of all withdrawals from the Euphrates-Tigris River system. Note that the question of water availability under a projected climate change also is not included in this equation. Moreover, the strong possibility that agricultural water requirements will decrease as a function of irrigated area introduces further uncertainty into this equation and is partially explored below.

Part of the reason for the large agricultural water use in the Sanliurfa-Harran irrigation district is increased cultivation of cotton. According to the DSI master plan, only $35 \%$ of the Harran Plain was originally set aside for cotton (DSI, 1992). The remainder of the area was planned for irrigation of a variety of other field crops and vegetables. Comparison of this plan with cultivation currently occurring in the Harran Plain draws immediate attention to the increased water demand. As the area irrigated increases to its full potential (roughly 10 times today's area), there may be a need to change the cropping pattern in the Harran Plain, from one dominated by cotton with high water demand to one that contains more variety with less demand for water.

The irrigation demand on the water resources of the GAP region is also affected by changes hydrometeorological conditions as irrigation schemes are progressively 
developed. Under the dry and windy conditions of the Harran Plain, close to 80\% of irrigation water applied in the field is consumptively used (Demir, 1999). As the total irrigated area increases, the area of the evaporating surface expands, greatly amplifying the amount of vapor released into the lower atmosphere. This large addition of vapor coupled by increased surface roughness subsequently affects the components of the hydrologic cycle, primarily evapotranspiration. These changes were a subject of two recent studies by Ozdogan and Salvucci (2004) and Ozdogan et al. (2006) who showed that computed potential evaporation (and thus crop water consumption) has declined as much as 15\% between 1993 (time of inauguration of irrigation schemes and large reservoirs) and 2002 under the framework of the Complementary Relationship (Bouchet, 1963). Similar decrease was also observed in pan evaporation. When decomposed, the Penman equation revealed that the decreasing trend in wind speed was far more important in this decline in potential evaporation than other variables such as radiation, air temperature, and more surprisingly, humidity (Ozdogan and Salvucci, 2004). As an extension of this work, Ozdogan et al. (2006) explain the decline in potential evaporation due to dynamical effects such as wind speed in the presence of irrigation as both as a result of increased surface roughness, increased atmospheric stability, and increased potential for locally generated wind speeds.

This reported decline in evaporative demand of the low-level atmosphere, manifested in potential evaporation, is, in essence, a positive development for irrigationrelated use of the water resources in the GAP region. The negative correlation between irrigated area and the amount of water required per unit area means less water demand on the Euphrates and Tigris rivers now and in the future. Indeed, the results based on the complementary relationship suggest that over $40 \%$ decrease in irrigation requirements can be expected under the high impact scenario in all project areas. This high impact scenario corresponds to the magnitude of effects already observed in the Harran Plain and thus may represent a conservative estimate.

\section{Conclusions}

The main goal of the current study was to document year-to-year changes in irrigated area and related agricultural water use with the help of remote sensing and ancillary data in the Sanliurfa-Harran Irrigation District, where the first phase of large-scale irrigation schemes have been implemented. These estimates not only help objectively determine the current volume of agricultural water withdrawal from the EuphratesTigris system, but also form a quantitative basis for understanding the current and future implications for region's water resources. Results indicate that the irrigated lands of the Harran Plain have increased by $\sim 300 \%$, expanding from over 35,000 ha to over 100,000 ha, with mean annual expansion rate of 10,000 hectares. Expansion has mostly occurred in central portions of the Harran Plain in the early half of the study period while marginal lands at the edges of the Harran Plain were increasingly utilized for production in the latter half of the study period. Accuracy assessment of 
each map indicates that the mean accuracy of the classification procedure is as high as $98 \%$ confirming confidence of the mapping procedure. Application of cotton crop consumptive requirements in the Plain reveals that the lower bound of annual volume of irrigation water use has also tripled during the study period, reaching over one billion cubic meters in 2002. These results point to a relatively large increase in agricultural water demand in Southeastern Turkey, although less than $10 \%$ of total irrigable area is currently developed. On the other hand, results of the supporting work by the authors based on Bouchet's Complementary Relationship suggest that a scale-dependence exists in the relationship between irrigated area and the amount of water required per unit area. A simplified prediction methodology based on this scale-dependence suggests that full irrigation development in the GAP region may lead to lesser water requirements per unit area in the long run.

\section{Acknowledgments}

This research was funded by NASA's Land Cover and Land Use Change (LCLUC) Program grant number NAG5-11338. We greatly acknowledge the USDA Foreign Agricultural Service (FAS) for providing the 1993, 1994, and 1996 imagery (FAS also owns the copyright of these three datasets). The efforts of Dr. Curt Reynolds at FAS are particularly appreciated. We thank the director of the Saudi Center for Space Research, Dr. Bin Turki, for providing the 1997 Landsat data free of charge. Mr. Öner Yorulmaz at the DSI kindly provided the data on actual irrigated area for each irrigation union in the Sanliurfa-Harran Irrigation District. We also thank two anonymous reviewers whose comments significantly improved this manuscript.

\section{References}

Abuzar, M., McAllister, A., and Morris, M., 2001, 'Classification of seasonal images for monitoring irrigated crops in a salinity-affected area of Australia', Int. J. Rem. Sen. 22, 717-726.

Beyribey, M., 1992, 'A study on irrigation water requirements and system capacity of GAP irrigation schemes', Ankara University, Department of Agricultural Sciences, publication 1245, Ankara (in Turkish).

Bouchet, R. J., 1963, 'Evapotranspiration reelle et potentielle, signification climatique, in General Assembly Berkeley', 62, 134-142, Int. Assoc. of Sci. Hydrol., Gentbrugge, Belgium.

Demir, H., 1999, 'The effect of GAP reservoirs and irrigation to climate parameters and reference crop water consumption, GAP I. Agricultural Congress, 26-28 May 1999, Sanliurfa (in Turkish).

Demir, H., 2003, 'The results of Sanliurfa-Harran Plain irrigation in 2002', GAP Review 16, 11, Ankara, (in Turkish).

Draeger, W., 1976, 'Monitoring irrigated land acreage using Landsat imagery: An application example', USGS Open-file Report No. 76-630, USGS, Sioux Falls, S.D. 23 pp.

DSI, 1988, 'Irrigation consumptive use and crop irrigation requirements in DSI irrigation schemes', DSI Internal Report, Ankara (in Turkish).

DSI, 1992, 'Final report on irrigation projects in the Sanliurfa-Harran and Mardin-Ceylanpinar Plains', DSI Internal Report, Ankara (in Turkish). 
Doorenbos, J. and Pruitt, W. O., 1977, 'Crop Water Requirements. Food and Agricultural Organization of the United Nations', Irrigation and Drainage Paper No. 24, Revised, Rome.

Eckhardt, D. W., Verdin, J. P., and Lyford, G. R., 1990, 'Automated update of an irrigated lands GIS using SPOT HRV imagery', Photogramm. Eng. Rem. Sen. 56, 1515-1522.

GAP, 1992, Integration of crop mosaic planning and marketing, GAP Administration Document, Vol 4, Appendix 5A and 5B, Ankara (in Turkish).

Gruen, G. E., 2000, 'Turkish waters: Source of regional conflict or catalyst for peace?', Water Air Soil Poll. 123, 565-579.

Hay, A. M., 1979, 'Sampling designs to test land use map accuracy', Photogramm. Eng. Rem. Sen. 45, 529-533.

Heller, R. C. and Johnson, K. A., 1979, 'Estimating irrigated land acreage from Landsat imagery', Photogramm. Eng. Rem. Sen. 45, 1379-1386.

Jensen, M. E., Burman, R. D. and Allen, R. G., 1990, Evapotranspiration and irrigation water requirements, ASCE Manuals and Reports on Engineering Practices No. 70., ASCE, New York, NY, $360 \mathrm{pp}$.

Kadioglu, M., 1998, Possible climate changes over Greater Anatolian Project (GAP), Proceedings of the International Symposium on Water Supply and Treatment, 25-26 May, Istanbul, pp. 65144.

Kadioglu, M. and Cepniler, B., 1998, Principal component analysis of precipitation regions in Turkey, Proceedings of ITU-DMI 2nd National Hydrometeorology Symposium, Ankara, 18-20 November, Ankara, pp.110-119 (in Turkish).

Karaata, H., 1985, Cotton consumptive use in the Harran Plain, General Directorate of Rural Services, Sanliurfa Research Institute Publication 24, Sanliurfa (in Turkish).

Kodal, S., Akuzum, T., Cakmak, B., and Kendirli, B., 1997, Irrigation scheduling for adequate and limited water application for some field crops in the Urfa region, 6th Kültürteknik Congress, Bursa, Turkey, pp. 354-362 (in Turkish).

Kolm, K. E. and Case, H. L., III, 1984, 'The identification of irrigated crop types and estimation of acreages from Landsat imagery', Photogramm. Eng. Rem. Sen. 50, 1479-1490.

Martinez-Beltran, C. and Calera-Belmonte, A., 2001, 'Irrigated crop estimation using Landsat TM imagery in La Mancha, Spain', Photogramm. Eng. Rem. Sen. 67, 1177-1184.

Morton, F. I., 1965, 'Potential evaporation and river basin evaporation', ASCE Journal of the Hydraulics Division 102(HY3), 275-291.

Ozdogan, M., 2004, 'The hydroclimatologic effects of irrigation in Southeastern Turkey', Ph.D. Dissertation, Geography Department, Boston University, 168 pp.

Ozdogan, M. and Salvucci, G. D., 2004, 'Irrigation-induced changes in potential evapotranspiration in southeastern Turkey: Test and application of Bouchet's complementary hypothesis', Water Resour. Res. 40, W04301, doi: 10.1029/2003WR002822.

Ozdogan, M., Salvucci, G. D., and Anderson, B. T., 2006, 'Examination of the Bouchet-Morton complementary relationship using a mesoscale climate model and observations under a progressive irrigation scenario', J. Hydromet. 7, 235-251.

Pax-Lenney, M., Woodcock, C. E., Collins, J. B., and Hamdi, H., 1996, 'The status of agricultural lands in Egypt: The use of multitemporal NDVI features derived from Landsat TM', Rem. Sen. Env. 56, 8-20.

Pax-Lenney, M. and Woodcock, C. E., 1997, 'The effect of spatial resolution on the ability to monitor the status of agricultural lands', Rem. Sen. Env. 61, 210-220.

Ram, B. and Kolarkar, A. S., 1993, 'Remote sensing applications in monitoring land use changes in arid Rajasthan', Int. J. Rem. Sen. 14, 3191-3220.

Roerink, G. J., Bastiaanssen, W. G. M., Chambouleyron, J., and Menenti, M., 1997, 'Relating crop water consumption to irrigation water supply by remote sensing', Water Resources Management 11, 445-465. 
Rundquist, D. C., Hoffman, R. O., Carlson, M. P., and Cook, A. E., 1989, 'The Nebraska Center-Pivot Inventory: An example of operational satellite remote sensing on a long-term basis', Photogramm. Eng. Rem. Sen. 55, 587-590.

Smith, M., 1992, 'CROPWAT - A computer program for irrigation planning and management', Irrigation and Drainage Paper No. 46, FAO, Rome, 126 pp.

Thelin, G. P. and Heimes, F. J., 1987, Mapping irrigated cropland from Landsat data for determination of water use from the High Plains Aquifer in parts of Colorado, Kansas, Nebraska, New Mexico, Oklahoma, South Dakota, Texas, and Wyoming, USGS Professional Paper 1400-C, Washington: U.S. Government Printing Office, 38 pp.

Thiruvengadachari, S., 1981, 'Satellite sensing of irrigation patterns in semiarid areas: an Indian study', Photogramm. Eng. Rem. Sen. 47, 1493-1499.

Tucker, C. J., Gatlin, J. A., and Schneider, S. R., 1984, 'Monitoring vegetation in the Nile Delta with NOAA-6 and NOAA-7 AVHRR imagery', Photogramm. Eng. Rem. Sen. 50, 53-61.

Ünver, O. I. H., 1997, 'Southeastern Anatolian Project (GAP)', Water Resour. Dev. 13, 453-483.

Wiegand, C. L., Everitt, J. H., and Richardson, A. J., 1992, 'Comparison of multispectral video and SPOT-1 HRV observations for cotton affected by soil salinity', Int. J. Rem. Sen. 13, 1511-1525. 